\title{
Painful neck swelling in a patient with end-stage renal disease on haemodialysis
}

\author{
Shabna Sulaiman, Jasmine Sethi, Harbir Singh Kohli, Krishan Lal Gupta
}

Nephrology, Post Graduate Institute of Medical Education and Research, Chandigarh, India

Correspondence to Professor Krishan Lal Gupta, klgupta@hotmail.com

Accepted 20 February 2019

\section{DESCRIPTION}

Acute suppurative thyroiditis (AST) is rarely seen as thyroid gland is highly resistant to infection due its thick capsule and high iodine content. ${ }^{1}$ Here, we report a case of successfully managed bacterial thyroid abscess in a patient of end-stage renal disease with catheter-related blood stream infection (CRBSI).

A 24-year-old woman presented to our hospital with fever and painful neck swelling for 25 days. Two months before present admission, she was diagnosed to have end-stage renal disease (chronic glomerulonephritis) and was initiated on haemodialysis via untunneled right internal jugular catheter. On examination, she had a temperature of $40^{\circ} \mathrm{C}$, pulse rate of $120 / \mathrm{min}$, blood pressure of $146 / 90 \mathrm{~mm} \mathrm{Hg}$ and there was a $5 \times 6 \mathrm{~cm}$ tender swelling in the anterior aspect of neck moving with deglutition. Laboratory parameters revealed severe anaemia (haemoglobin $52 \mathrm{~g} / \mathrm{L})$, leucocytosis $\left(28 \times 10^{9} / \mathrm{L}\right.$ with neutrophilic predominance), hypoalbuminaemia $(2.3 \mathrm{~g} / \mathrm{dL})$ and procalcitonin of $15.7 \mathrm{ng} / \mathrm{mL}$. Paired blood cultures from the catheter hub and peripheral blood on day 1 of admission grew Stenotrophomonas maltophilia and methicillin-resistant Staphylococcus aureus sensitive to vancomycin. Thyroid function tests showed elevated T3 $(3.78 \mathrm{ng} / \mathrm{mL}), \mathrm{T} 4(24 \mu \mathrm{g} / \mathrm{dL})$ and thyroid stimulating hormone $(7.87 \mu \mathrm{IU} / \mathrm{ml})$. Sonography of the neck showed multiple echogenic lesions seen in both lobes of the thyroid gland likely thyroiditis with evolving abscess. Trans-esophageal echocardiogram did not reveal any vegetation. Contrast-enhanced

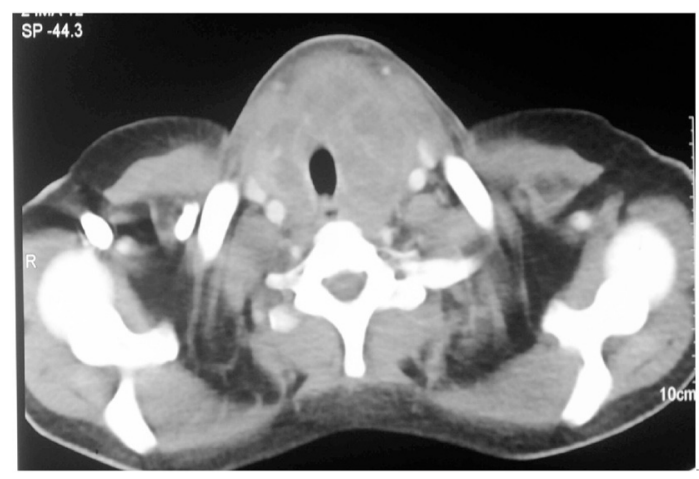

Figure 1 Intravenous contrast-enhanced CT scan of the neck (axial view) showing a large swelling in anterior aspect of neck with hypodense areas suggestive of thyroid abcess. computed tomography of the neck, chest and abdomen was done to look for extension of abscess or any focus of haematogenous spread, revealed only the thyroid abscess with no extrathyroid extension (figure 1). Ultrasound-guided aspiration from the swelling revealed a cloudy fluid with neutrophil-rich infiltrates, and mycobacterial, bacterial and fungal cultures were sterile. Thyroid abcess aspiration was done 3 days after the start of antibiotics, which could explain sterile bacterial culture. A diagnosis of bacterial multidrug-resistant thyroid abscess due to CRBSI and haematogenous spread was considered. Catheter was removed and parenteral antibiotics (vancomycin and levofloxacin) were administered for 4 weeks. The patient became afebrile with resolution of the neck swelling after a week. Arteriovenous fistula was created and a tunnelled right internal jugular catheter was inserted.

Thyroid abcess is very rare and no case of thyroid abcess secondary to CRBSI has been reported so far. The increased susceptibility to infection may be multifactorial in our patient-chronic kidney disease being an immunosuppressed state, CRBSI as well as repetitive exposure to pathogens during haemodialysis. ${ }^{2} \mathrm{~A}$ clinician should always suspect thyroid abscess in a patient with acute onset painful neck swelling.

\section{Learning points}

- Always consider acute suppurative thyroiditis as a cause of painful neck swelling in immunocompromised patients.

- Ultrasound is the preferred imaging modality to diagnose this entity.

- Prompt antimicrobial and drainage of thyroid abcess should be done to improve the survival.

Contributors SS and JS: concept and design and drafting. HSK and KLG: final approval, editing and proof reading.

Funding The authors have not declared a specific grant for this research from any funding agency in the public, commercial or not-for-profit sectors.

Competing interests None declared.

Patient consent for publication Obtained.

Provenance and peer review Not commissioned; externally peer reviewed.

\section{REFERENCES}

1 Berger SA, Zonszein J, Villamena P, et al. Infectious diseases of the thyroid gland. Rev Infect Dis 1983;5:108-22.

2 Wang HE, Gamboa C, Warnock DG, et al. Chronic kidney disease and risk of death from infection. Am J Nephrol 2011;34:330-6. 
Copyright 2019 BMJ Publishing Group. All rights reserved. For permission to reuse any of this content visit https://www.bmj.com/company/products-services/rights-and-licensing/permissions/

BMJ Case Report Fellows may re-use this article for personal use and teaching without any further permission.

Become a Fellow of BMJ Case Reports today and you can:

- Submit as many cases as you like

- Enjoy fast sympathetic peer review and rapid publication of accepted articles

Access all the published articles

- Re-use any of the published material for personal use and teaching without further permission

For information on Institutional Fellowships contact consortiasales@bmjgroup.com

Visit casereports.bmj.com for more articles like this and to become a Fellow 